\title{
The future for Mediterranean wetlands: 50 key issues and 50 important conservation research questions
}

\author{
Nigel G. Taylor ${ }^{1}$ (D) $\cdot$ Patrick Grillas $^{1} \cdot$ Hazem Al Hreisha ${ }^{2} \cdot$ Özge Balkız $^{3}$ - Maud Borie ${ }^{1,4}$ • Olivier Boutron ${ }^{1}$. \\ Ana Catita ${ }^{5,6,7}$. Jocelyn Champagnon ${ }^{1} \cdot$ Semia Cherif $^{8} \cdot$ Kerim Çiçek $^{9} \cdot$ Luís T. Costa $^{10} \cdot$ Mohamed Dakki $^{11,12}$. \\ Mauro Fois ${ }^{13}$. Thomas Galewski ${ }^{1}$ - Alessandro Galli ${ }^{14}$ - Nicholas M. Georgiadis ${ }^{15}$ - Andy J. Green ${ }^{16}$. \\ Virgilio Hermoso ${ }^{17,18}$ - Rezart Kapedani ${ }^{19}$ - Manfred A. Lange 20,21 . Zoran Mateljak ${ }^{22}$ - Maher Osta ${ }^{23}$. \\ Eva Papastergiadou ${ }^{24}$ - Clairie Papazoglou ${ }^{25}$. Sergi Sabater ${ }^{26,27}$ • Boudjéma Samraoui ${ }^{28,29}$ • Farrah Samraoui ${ }^{29,30}$. \\ Abdelkrim Si Bachir ${ }^{31} \cdot$ Eva Tankovic $^{32}$ - Mathieu Thévenet ${ }^{32} \cdot$ Antonio Troya $^{33} \cdot$ William J. Sutherland $^{34}$
}

Received: 5 June 2020 / Accepted: 28 December 2020 / Published online: 21 March 2021

(C) The Author(s), under exclusive licence to Springer-Verlag GmbH, DE part of Springer Nature 2021

\begin{abstract}
Wetlands are critically important for biodiversity and human wellbeing, but face a range of challenges. This is especially true in the Mediterranean region, where wetlands support endemic and threatened species and remain integral to human societies, but have been severely degraded in recent decades. Here, in order to raise awareness of future challenges and opportunities for Mediterranean wetlands, and to inform proactive research and management, we identified (a) 50 key issues that might affect Mediterranean wetlands between 2020 and 2050, and (b) 50 important research questions that, if answered, would have the greatest impact on the conservation of Mediterranean wetlands between 2020 and 2050. We gathered ideas through an online survey and review of recent literature. A diverse assessment panel prioritised ideas through an iterative, anonymised, Delphi-like process of scoring, voting and discussion. The prioritised issues included some that are already well known but likely to have a large impact on Mediterranean wetlands in the next 30 years (e.g. the accumulation of dams and reservoirs, plastic pollution and weak governance), and some that are currently overlooked in the context of Mediterranean wetlands (e.g. increasing desalination capacity and development of antimicrobial resistance). Questions largely focused on how best to carry out conservation interventions, or understanding the impacts of threats to inform conservation decision-making. This analysis will support research, policy and practice related to environmental conservation and sustainable development in the Mediterranean, and provides a model for similar analyses elsewhere in the world.
\end{abstract}

Keywords Horizon scan $\cdot$ Foresight $\cdot$ Ramsar $\cdot$ Aquatic ecosystems $\cdot$ Europe $\cdot$ Middle East and North Africa

\section{Introduction}

Wetlands are critically important to both biodiversity and human wellbeing. For their area, wetlands support a disproportionate amount of global biodiversity (Balian et al. 2008) and contribute disproportionately to ecosystem service provision (Davidson et al. 2019). Conservation and wise use of wetlands can contribute to fulfilment of the United Nations Sustainable

Communicated by Christopher Reyer

Nigel G. Taylor

taylor@ tourduvalat.org; ngltaylor@yahoo.com

Extended author information available on the last page of the article
Development Goals (Ramsar Convention on Wetlands 2018) and protection against floods and other extreme weather events, as recognised in the Sendai Framework for Disaster Risk Reduction (Sebesvari et al. 2019).

In the Mediterranean, wetlands include lagoons and salt marshes, freshwater lakes, karstic cave systems, temporary ponds, artificial wetlands such as reservoirs, salinas, fish ponds and rice paddies, small and scattered peatlands, and one of the longest rivers in the world (Balbo et al. 2017; Payne 2018). Although wetlands occupy only $2-3 \%$ of the land area of the Mediterranean basin (Fig. 1), more than $30 \%$ of the region's vertebrate species depend on them (MWO 2018). Since ancient times, Mediterranean wetlands have provided food, water, building materials, and other ecosystem services that contribute to human wellbeing (Hefny 
Fig. 1 Overview of the extent of Mediterranean wetlands; note that these data are illustrative only and do not exactly match the scope of our horizon-scanning and question-setting exercise (cf. Fig. 2 ). The area of each circle is proportional to wetland area. Yellow-orange-red circles represent continental surface wetlands; shading indicates the percentage of each country covered by wetlands. Blue circles represent marine wetlands $(<6 \mathrm{~m}$ water depth at low tide) on the Mediterranean coast of each country, plus Atlantic coasts for Morocco and Portugal. Data from Perennou et al. (2012) and MWO (2018). Data for Andorra, Gibraltar, San Marino and Vatican City not available

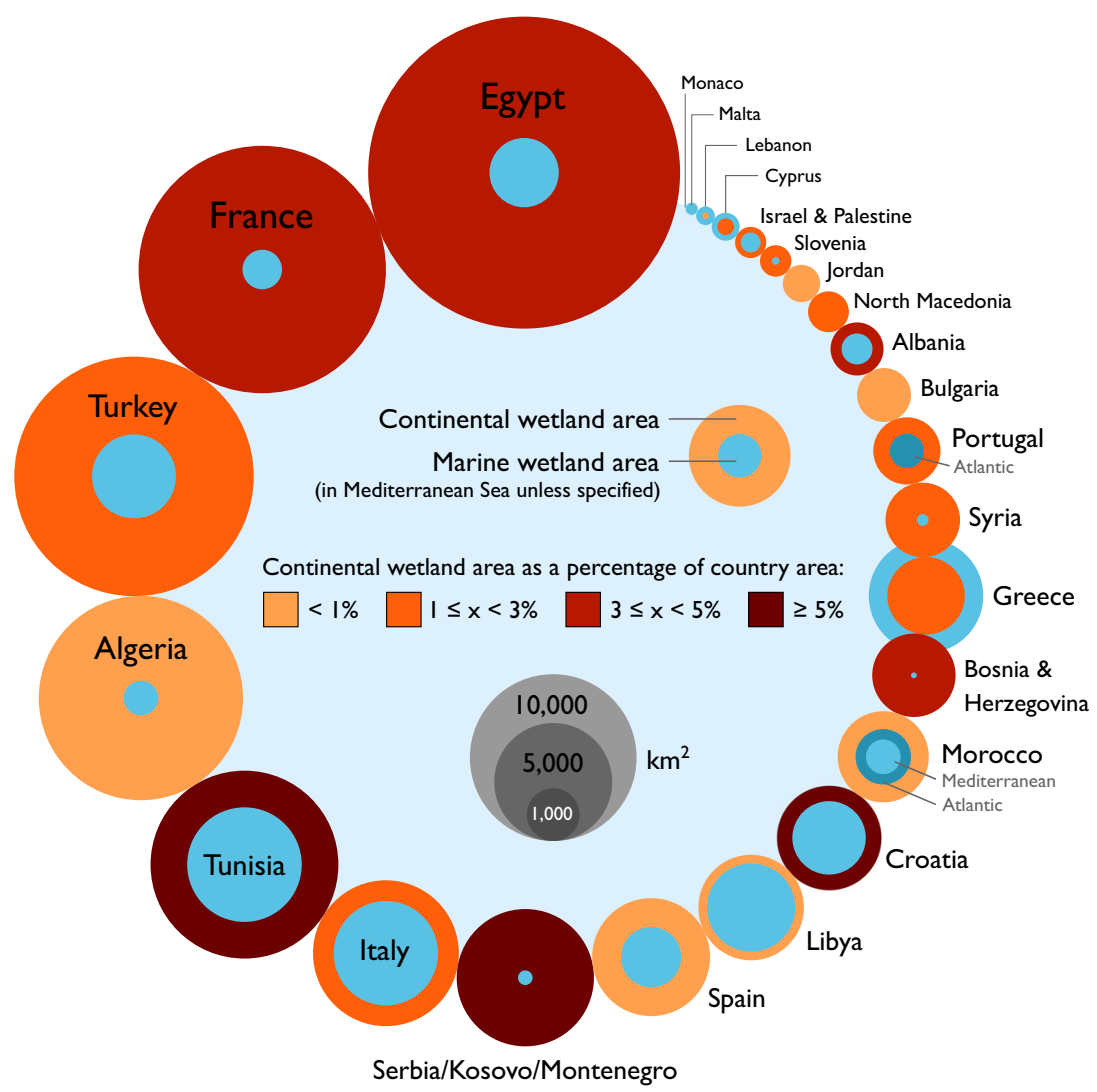

and Amer 2005; Ferrari et al. 2013; Walsh et al. 2014). They have also permeated human culture: water and reeds were used as Ancient Egyptian hieroglyphs, the town of Arles in France holds ferias with games involving Camargue bulls, and the Narta Lagoon in Albania is celebrated with an annual festival (Papayannis 2008). Some wetland species have become iconic and closely associated with regional identities, as in the case of the greater flamingo Phoenicopterus roseus in the Camargue, France and Fuente de Piedra, Spain (Balkız et al. 2010; Ernoul and Wardell-Johnson 2016).

Meanwhile, and with local variations on the overall trend, Mediterranean wetlands and their biodiversity are in sharp decline. For example, the Mediterranean lost approximately $50 \%$ of its natural wetland surface area over the twentieth century (Perennou et al. 2012) and a sample of natural wetland sites shrunk by 45-51\% on average between 1970 and 2013 (MWO 2018). Wetland-dependent amphibians, reptiles, mammals, fish, odonates and orthopterans have all recently experienced large declines in abundance over recent decades (MWO 2018; Fraixedas et al. 2019). Critically Endangered species include the Adriatic sturgeon Acipenser naccarii, the Greek red damselfly Pyrrhosoma elisabethae and the beautiful water-starwort Callitriche pulchra (IUCN 2020). Historically, Mediterranean wetlands have been drained or highly sanitised for agricultural use, development of tourist areas and perceived health benefits (Balbo et al. 2017; Parrinello and Bécot 2019). Contemporary challenges for
Mediterranean wetlands include rapid urbanisation, increased water usage, climate change and land conversion (MWO 2018). Although several foresight projects have been carried out with implications for the Mediterranean (Kark et al. 2016; Moreira et al. 2019), aquatic systems (Brown et al. 2010; Pérez-Jvostov et al. 2020) and environmental conservation more generally (Sutherland et al. 2009; UNEP 2017; Ockendon et al. 2018; Sutherland et al. 2020; Esmail et al. 2020), there remains a need for analyses focused on the nexus of these topics: Mediterranean wetlands and their conservation.

Foresight analyses can help facilitate strategic, proactive, effective and efficient management (Sutherland and Woodroof 2009; Cook et al. 2014; Wintle et al. 2020). Horizon scanning is an established tool for the systematic examination of future problems, threats and opportunities, including those that are well known at present but likely to continue or increase in importance, and those that are novel and unexpected and at the margins of current thinking (van Rij 2010; Wintle et al. 2020). It involves an initial stage of gathering multiple potentially relevant ideas across diverse streams of information, then subsequent stages of refinement and prioritisation by experts and stakeholders (Amanatidou et al. 2012). Ultimately, horizon scanning should produce digestible, policy-relevant information that can inform further decision-making processes (Cook et al. 2014). A similar process of information gathering, followed by refinement and 
prioritisation, can be used to identify priority research questions which, if answered, would most advance knowledge, policy or practice in a particular subject area (Sutherland et al. 2011; Kark et al. 2016; Moreira et al. 2019).

Here, focusing on the timeframe 2020-2050, we identified 50 key issues that might affect Mediterranean wetlands and 50 important research questions that, if answered, would most help efforts to conserve Mediterranean wetlands.

\section{Methods}

\section{Scope}

For this exercise, we adopted a broad definition of wetlands: areas of marsh, swamp, peatland or water, whether natural or artificial, permanent or temporary, with water that is static or flowing, fresh, brackish or salt, including areas of marine water the depth of which at low tide does not exceed six metres (Ramsar Convention Secretariat 2016). We defined Mediterranean wetlands (Fig. 2) as wetlands:

a) Within the Mediterranean biome or related ecoregions (Mediterranean conifer and mixed forests, Mediterranean High Atlas juniper steppe, Apennine deciduous montane forests, Central Anatolian steppe and woodlands, Eastern Anatolian deciduous forests, and selected Saharan halophytics; Dinerstein et al. 2017)

b) Within coastal watersheds that drain into the Mediterranean Sea (Lehner and Grill 2013) c) In the sea along any coast of those areas (GEBCO 2020)

Naturally, activities in watersheds upstream of the study area (e.g. upstream of Aswan on the River Nile) may also fall within the scope of the current project because of their impacts on wetlands downstream. Issues and questions could be related to any aspect of Mediterranean wetlands, inter alia their extent, physical characteristics, biodiversity, productivity, recreational use, heritage value and cultural value.

We defined two types of key issues that might affect Mediterranean wetlands over the next 30 years. Critical issues are those that are most likely to have a large impact on Mediterranean wetlands. Overlooked issues are those likely to have a large impact on Mediterranean wetlands, but which are currently not well known amongst Mediterranean wetland stakeholders. Many environmental horizon-scanning projects focus on these latter emerging issues (e.g. Kark et al. 2016; Pérez-Jvostov et al. 2020; Sutherland et al. 2020; Wintle et al. 2017). However, we felt it was valuable to also highlight persistent issues, regardless of novelty, to give a complete picture of the challenges and opportunities facing Mediterranean wetlands (van Rij 2010; Cranfield University 2018).

We defined important research questions as questions that, if answered, would have the largest impact on the conservation of Mediterranean wetlands over the next 30 years. Questions could be answered by primary research or syntheses of existing literature. We originally intended that the questions would be precise enough to be answered through a scientific research programme of a few years' duration (Sutherland et al. 2011),

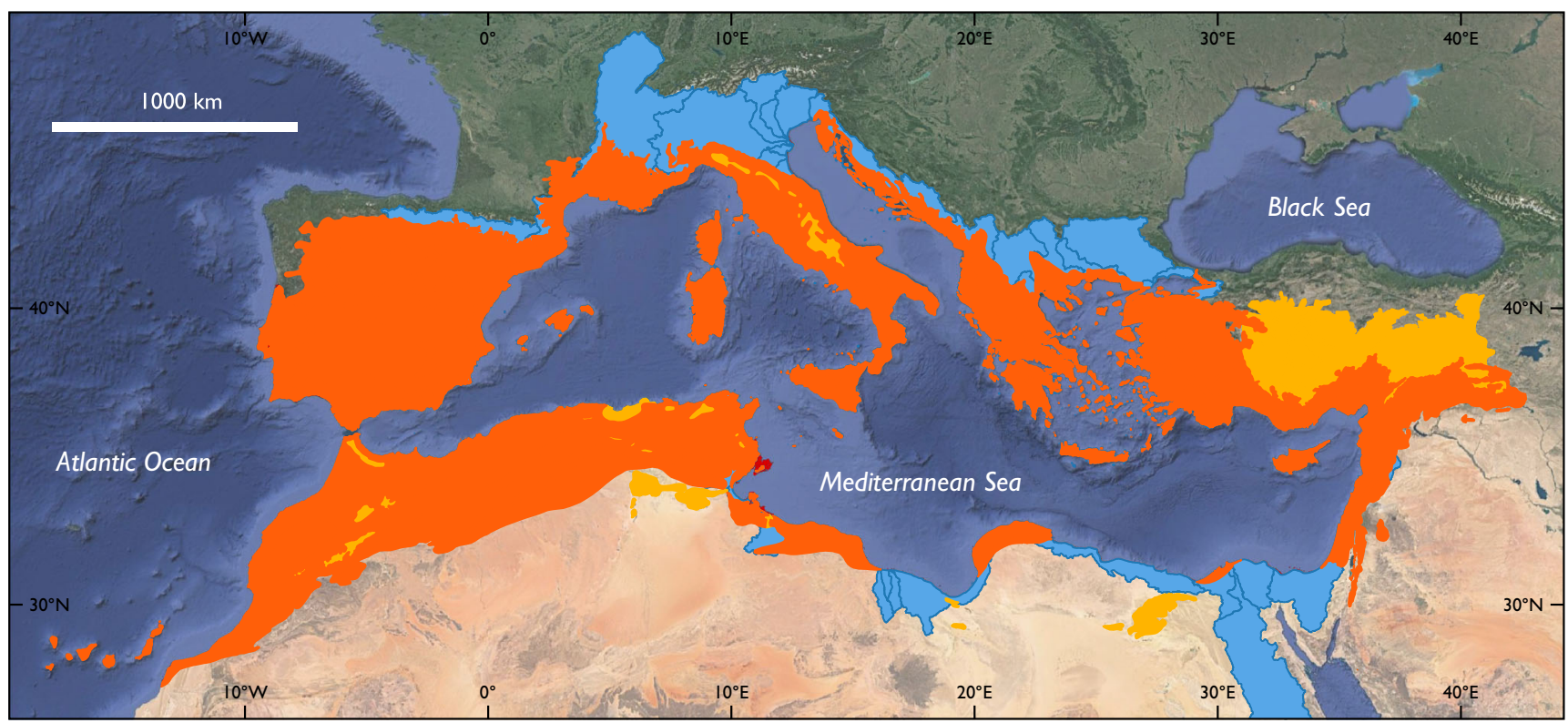

Fig. 2 The geographical scope of the horizon-scanning and questionsetting exercise. The focus was on wetlands within the Mediterranean biome (dark orange) or related ecoregions (light orange), within coastal watersheds that drain into the Mediterranean Sea (blue) and in the sea along any coast of those areas (red, generally limited to a very narrow strip just offshore). Data sources: Dinerstein et al. (2017), Lehner and Grill (2013), GEBCO (2020), Google/TerraMetrics. Map Projection: World Mercator 
but this precision was relaxed based on the scope of the survey responses we received. Thus, our research questions are best considered as broad research areas within which more focused questions should be developed.

\section{Gathering ideas}

An online survey was created to solicit ideas from a geographically, demographically and intellectually diverse range of participants (Fig. 3; Esmail et al. 2020; Wintle et al. 2020). The survey was available via www.surveymonkey.com in MayJune 2019, in three languages (English, French and Arabic). It was publicised to a list of over 1600 e-mail contacts of Tour du Valat, with posts in several languages on social media (Twitter, Facebook, ResearchGate), and in online fora. Participants were invited to submit issues and research questions. Some basic demographic information was also collected (Appendix 1a). A total of 135 individuals based in 24 countries (19
Mediterranean) responded to the survey, although most participants (53\%) were based in France. Participants had diverse expertise, although most commonly in nature management and/or biological science (Appendix 1b). Most participants were affiliated with governmental, non-governmental and/or research organisations (Appendix 1b).

Further ideas were collated through an ad hoc literature review (Fig. 3). This involved internet and literature database searches, systematic screening of recent articles in scientific journals, and inspection of recent horizon-scanning and question-setting publications (Appendix 1c). The aim of this review was to generate ideas that may be outside current thinking of survey participants, and feed these into the pool for expert assessment.

The initial 954 issues and 408 questions gathered through the survey and literature review were refined by the facilitator (NGT). All responses were translated to English and duplicates were merged. Responses suggesting actions rather than
Fig. 3 An overview of the process used to derive key issues and important research questions for Mediterranean wetlands. Yellow boxes track the number of issues and questions through the process; large bold numbers indicate shortlisted issues/ questions at each stage (see main text), whilst small numbers in parentheses indicate rejected issues/questions, presented to assessors for reference. Green boxes show processes involving input from survey participants or assessors. Blue boxes show processes carried out by the facilitator. Processing involved editing items for clarity and granularity, merging similar items, calculating raw scores and $Z$ scores (for issues) or tallying votes (for questions), identifying items with highest scores or most votes, researching items to provide supporting or contradictory evidence, and regrouping into broader themes

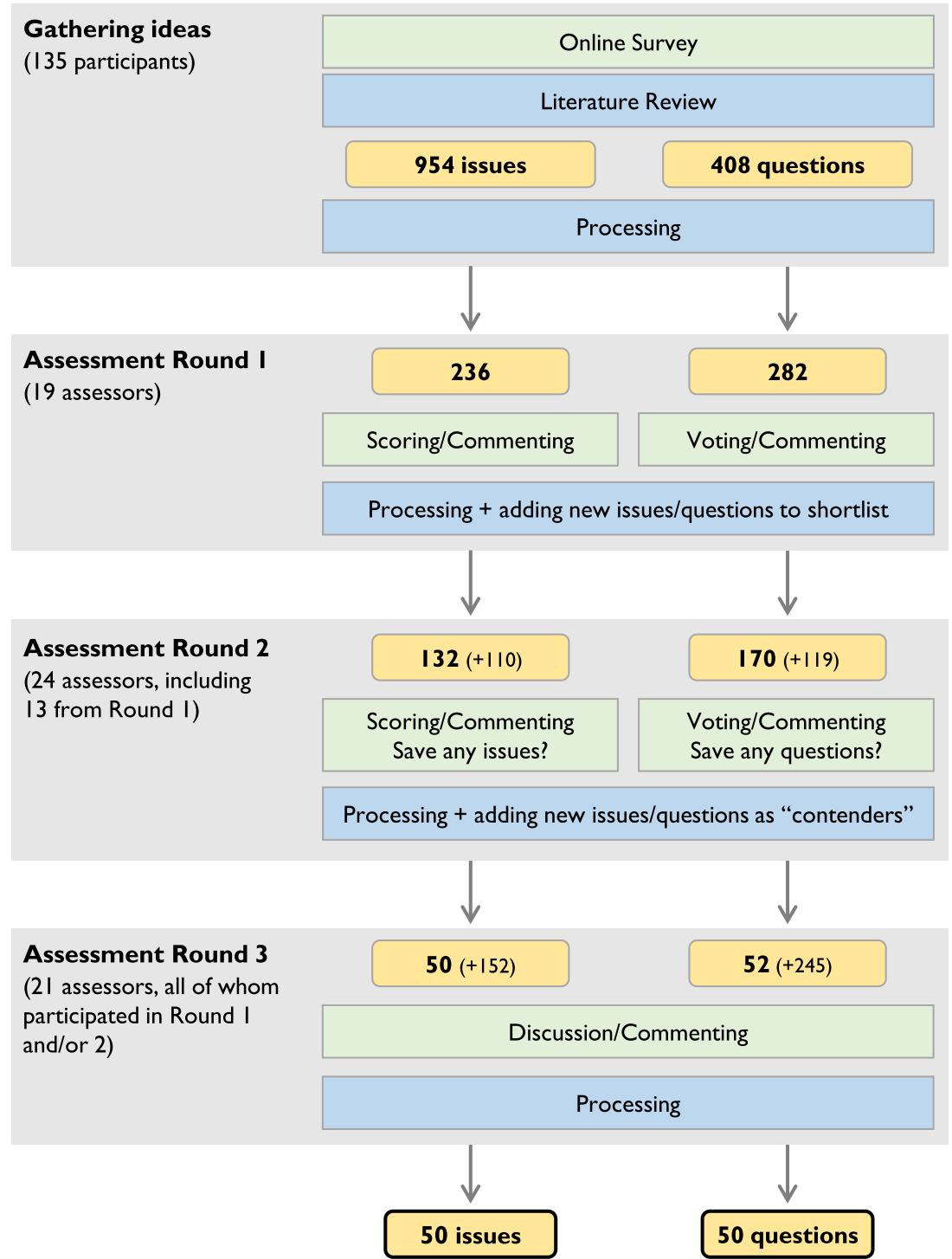


issues or research questions, and vague/broad responses (e.g. climate change, invasive species, pollution) were removed or refined. The remaining 236 issues and 282 questions were organised into 18 themes.

\section{Expert assessment}

Three rounds of expert assessment were carried out (Fig. 3), following a Delphi-like process to prioritise the issues and questions iteratively and anonymously (Mukherjee et al. 2015; Wintle et al. 2020). Expert assessors were selected to achieve diversity in terms of geography, expertise, affiliation, and gender (Appendix 1b). At least 18 of the 30 assessors had expertise about each of four major Mediterranean sub-regions (Western Europe, Balkans, Near East, Maghreb). Thirteen considered themselves to have knowledge spanning the whole Mediterranean. Most assessors classified their expertise as biology (20 assessors; 67\%), nature management (14; 47\%) and/or the physical/chemical environment $(11 ; 37 \%)$. Ten assessors $(33 \%)$ completed the original online survey.

In Rounds 1 and 2, assessors scored the issues on Likelihood (L; how likely the issue is to have any impact on Mediterranean wetlands in the next 30 years, ignoring the size of that impact), Impact (I; the size of the impact this issue would have on Mediterranean wetlands, assuming it were to occur; "size" incorporates both the intensity and spatial extent of the impact) and Novelty (N; relating to how well known the issue is in the context of Mediterranean wetlands). Assessors also voted for important research questions, voting for the top ca. $20 \%$ of questions within each theme. Assessors were sent one of three sheets with a randomised order of themes, and of issues or questions within each theme. They were free to score as many issues and aspects (L, I and N), and vote for as many questions, as they felt comfortable doing. Assessors were also instructed to comment on issues/questions (e.g. identifying overlap, suggesting new phrasing, providing supporting information) and could suggest new issues/questions. In Round 2, they could also identify rejected issues/questions that they wished to save. Assessment sheets were completed independently and sent back to the facilitator.

Between rounds, the facilitator created shortlists to be carried forward. These included issues with the highest scores for $\mathrm{L} \times \mathrm{I}$ and $\mathrm{L} \times \mathrm{I} \times \mathrm{N}$, and questions receiving the most votes. New issues/questions suggested in Round 1 were also included in the shortlist for Round 2 (cf. inclusion as "contenders" for Round 3). Guided by assessor comments, the facilitator also edited, merged and removed issues/questions, refined the supporting information, and merged/renamed themes.

In Round 3, the shortlists were refined through an open online discussion. Assessors indicated where they strongly agreed or disagreed with inclusion of an issue/question in the shortlist, and where they strongly felt a rejected issue/question should be included. "Contender" issues/questions were highlighted, i.e. those that had just missed being shortlisted in
Round 2, received votes to be saved in Round 2, or newly identified in Round 2. Assessors also made comments as in Rounds 1 and 2. Final revision of the shortlist was based primarily on comments in Round 3, with consideration of scores/ votes in previous rounds where necessary (see Appendix 1d).

\section{Results}

The 50 key issues and 50 important research questions arising from our assessment are listed in Tables 1 and 2. Within these tables, the issues and questions are grouped into themes and are not ranked by score or number of votes. However, within each theme, the highest-scoring issue and the question receiving the most votes is marked with an asterisk. Appendices 2 and 3 provide more detailed supporting information for each issue and question. The following text exposes the issues and questions with narratives around nine themes. Text in square brackets refers to issues [I] or questions [Q]. Critical issues are numbered 1-25 and overlooked issues are numbered 26-50.

\section{Agriculture and aquaculture}

Agricultural activities can have direct and indirect effects on Mediterranean wetlands. In the future, we expect an expansion of agricultural surface area [I1], at least locally, which may drive loss of wetlands and increase exposure to pollution for those which remain. We also expect increased use of pesticides, antimicrobials and fertilisers in agriculture [I2], but acknowledge that this may be limited by regulation, for example in the EU [126]. Issues related to water use in agriculture, which accounts for $65 \%$ of total water use in the Mediterranean (MWO 2018), are considered in the following section.

Aquacultural production in Mediterranean wetlands has been increasing over the past decades and is likely to increase further in the future [I3], through a combination of intensification and expansion - although local abandonment also remains a possibility.

We retained two important research questions relating to agriculture and aquaculture. These concerned the impacts of agricultural chemicals [Q1] and livestock grazing [Q2] on Mediterranean wetlands and how such impacts can be mitigated.

\section{Water and pollution}

Many of the key issues for Mediterranean wetlands are related to water use. Demand for water in the Mediterranean will likely increase due to the growing human population (UNEP/MAP 2012), agricultural expansion and climatic changes. Climate change will also reduce water availability. Four of our issues are related to the balance between water supply and demand, namely increasing water abstraction from both ground and surface water sources [I4], a proliferation of dams and reservoirs of varying scale 
Table 1 Fifty key issues for Mediterranean wetlands 2020-2050. The list is split into (a) 25 critical issues, most likely to have a large impact on Mediterranean wetlands (highest Likelihood $\times$ Impact score), and (b) 25 overlooked issues, likely to have a large impact on Mediterranean wetlands, but not currently well known in the context of Mediterranean wetlands (highest Likelihood $\times$ Impact $\times$ Novelty score, once the critical issues had been removed). The order of the issues does not reflect their score, but the highest-scoring issue within each theme is marked with an asterisk (*). For further definition and description of each issue, including discussion of how it threatens and/or presents opportunities for Mediterranean wetlands, see Appendix 2

(a) 25 CRITICAL ISSUES

Agriculture and aquaculture

1. Expansion of agriculture*

2. Increasing use of synthetic chemicals in agriculture

3. Increasing aquacultural production

Water and pollution

4. Increasing water abstraction*

5. Accumulation of dams/reservoirs, built for water storage and/or energy production

6. Increasing agricultural water use efficiency

7. Salinisation of freshwater wetlands

8. Plastic pollution

9. Poor wastewater treatment infrastructure, especially in urban areas

Physical environment and climate change

10. Increasing average and maximum temperatures

11. Declining total precipitation, increased drought severity and desertification*

12. Increasing frequency and intensity of storms

13. Sea level rise

Biotic environment, ecology, biodiversity

14. Increasing number and expanding distribution of alien species*

15. Increased frequency, intensity and distribution of algal blooms

16. Declining populations, and extinctions, of Mediterranean wetland species

17. Fragmentation of wetland habitats

Ecosystem services and use of wetlands

18. Traditional livelihoods, that use wetlands sustainably, become less common*

\section{Socioeconomics}

19. Increasing tourist numbers

20. Urban growth*

21. Socioeconomic impacts of climate change

\section{Governance}

22. Weak and ineffective governance*

23. Creation of weak laws regarding conservation or wise use of Mediterranean wetlands

24. Subsidies, even those intended to be environmentally beneficial, encourage degradation or conversion of Mediterranean wetlands

Management and monitoring

25. Artificialisation of Mediterranean wetlands*

\section{(b) 25 OVERLOOKED ISSUES}

Agriculture and aquaculture

26. Increasing regulation (e.g. bans) on pesticide use*

Water and pollution

27. Increasing desalination capacity*

28. Increasing concentrations of domestic and medical pollutants in Mediterranean wetlands 
Table 1 (continued)

29. Deliberate dumping of solid waste in or near Mediterranean wetlands

Physical environment and climate change

30. Increased frequency of dust storms

31. Increased fire risk within Mediterranean wetlands and their watersheds*

Biotic environment, ecology, biodiversity

32. Spread of novel wildlife pathogens and diseases*

33. Development of antimicrobial resistance within Mediterranean wetlands

34. Spread of mosquito-borne diseases

35. Development of insecticide resistance in mosquitoes

Ecosystem services and use of wetlands

36. Sand and gravel extraction*

Socioeconomics

37. Political and socioeconomic instability

38. Poverty, especially in south and east Mediterranean countries

39. Development of a "blue economy" focused on sustainable use of the Mediterranean Sea

40. Changing attitudes to economic development, with increasing priority to social and natural capital over financial capital*

41. Limited funding for conservation of Mediterranean wetlands, especially research and monitoring

Governance

42. Missing or inadequate national wetland policies

43. Improved communications bring Mediterranean wetlands on to the policy agenda*

Management and monitoring

44. Management of transboundary wetlands

45. Development of eDNA and eRNA technology for monitoring Mediterranean wetlands and their biodiversity*

46. Use of artificial intelligence/machine learning to process data

47. Smart urban water management

48. Increasing quality and declining cost of drones

49. Use of social media for tracking human interaction with environment

50. Development of regional networks for sharing knowledge about Mediterranean wetland management

[I5], increasing desalination capacity [I27], and continued improvements in agricultural water use efficiency, whether through technological or behavioural means [I6 and Q3]. These issues present both opportunities and threats to Mediterranean wetlands. For instance, abstraction and dams may reduce the quantity and quality of water available to natural wetlands. Abstraction, especially from coastal wetlands, will contribute to salinisation of groundwater and freshwater wetlands [I7]. New and highcapacity desalination plants could reduce competition for inland water between humans and wetlands, but introduce their own problems regarding pollution from waste brine and energy consumption (Plan Bleu 2010).

Four other issues related to pollution made our list: plastic pollution [I8], poor wastewater treatment infrastructure [19], increasing aquatic concentrations of domestic and medical pollutants [I28] and solid waste dumping [I29]. The first issue includes pollution from both macro- and micro-plastics, but the extent and impacts of the latter in Mediterranean wetlands are not well understood [Q4]. Similarly, it is important to understand the effects of emerging chemical pollutants such as caffeine, triclosan, oestrogen, ibuprofen and illicit drugs [Q5], the aquatic concentrations of which may increase in line with growth and ageing of the human population, and changes in socioeconomic status. Active compounds may be passed out in human urine and may not be removed by water treatment processes even where these are available. Around $37 \%$ of large coastal settlements across the Mediterranean do not operate a wastewater treatment plant (UNEP/MAP 2012), and many of those that do exist fail to meet regulatory standards (EEA 2019). 
Table 2 Fifty important research questions for the conservation of Mediterranean wetlands 2020-2050. If answered, these questions should have a large impact on Mediterranean wetland conservation. The order of the questions does not reflect the number of votes they received, but the question receiving the most votes within each theme is marked with an asterisk (*). For further definition and exploration of each question, including some relevant references, see Appendix 3

Agriculture and aquaculture

1. How can we minimise the impacts of agricultural chemicals on nearby wetlands?*

2. What is the impact of livestock grazing on Mediterranean wetlands, and how can undesirable impacts be mitigated?

Water and pollution

3. How do economic incentives for water-efficient agriculture affect water use on Mediterranean farms?

4. What is the extent of microplastic pollution in Mediterranean wetlands, and what impact does it have on wildlife and human health?

5. What are the effects of emerging domestic and medical pollutants on wildlife in Mediterranean wetlands?*

Physical environment and climate change

6. Which Mediterranean wetlands are most vulnerable to climate change, particularly associated changes in hydrological regimes?

7. How will relative sea level rise impact coastal Mediterranean wetlands?

8. How will Mediterranean wetland biodiversity respond to future climate change?*

9. To what extent will Mediterranean wetlands provide climate change refugia for biodiversity?

10. How will acidification affect Mediterranean wetlands, both coastal and inland?

Biotic environment, ecology, biodiversity

11. Which invasive species have the greatest potential to negatively impact Mediterranean wetlands over the next 30 years?

12. How can we prevent the spread of invasive species within and between Mediterranean wetlands?

13. What are the critical factors affecting the population dynamics of the most endangered animal and plant species in Mediterranean wetlands?

14. What is the role/value of temporary wetlands for biodiversity in the Mediterranean?

15. How resistant and resilient are Mediterranean wetlands to disturbance? What factors, including human activities, affect resistance and resilience?*

16. How do/will dams and altered flow regimes affect organisms in Mediterranean wetlands?

17. How does/will light pollution affect organisms in Mediterranean wetlands?

18. How do Mediterranean wetlands interact with neighbouring ecosystems?

19. What is the role of Mediterranean wetlands in spreading antimicrobial resistance, or as hotspots for evolution of antimicrobial resistance?

Ecosystem services and use of wetlands

20. What level of sustainable use can be tolerated by Mediterranean wetlands? Where are the thresholds above which damage occurs?

21. What is the relationship between ecosystem condition and service provision in Mediterranean wetlands?

22. How do the services and habitat provided by artificial Mediterranean wetlands differ from natural Mediterranean wetlands? Can they compensate for lost natural wetlands?

23. How can Mediterranean wetlands contribute to societal adaptation to climate change?*

24. What is the role of Mediterranean wetlands in the carbon cycle? How might they be used in climate change mitigation?

25. What is the relationship between Mediterranean wetlands and human health? How do human health effects of Mediterranean wetlands align with, or trade off with, other ecosystem services?

Socioeconomics

26. What land use and land management conflicts will emerge in the Mediterranean over the next 30 years? How can they be addressed?

27. How can we balance human development and conservation of Mediterranean wetlands?*

28. How can the private sector be engaged in the conservation of Mediterranean wetlands?

29. What is the net economic value of Mediterranean wetlands and the services they provide? How is this accounted for in public accounts?

30. What is the net cost/benefit of conserving Mediterranean wetlands?

31. How are Mediterranean wetlands perceived by society? How have these perceptions changed/how are they changing?

32. What strategies are effective for (a) increasing public understanding of the importance of Mediterranean wetlands, and (b) changing public behaviour to have less impact on Mediterranean wetlands?

\section{Governance}

33. How do governance settings affect wetland management and conservation in the Mediterranean?*

34. How can we improve the efficacy of the science-policy interface related to Mediterranean wetlands?

35. What are effective framings for ensuring Mediterranean wetlands are incorporated into policy decisions?

Management and monitoring

36. How can we help Mediterranean wetlands cope with climate change 
Table 2 (continued)

37. How can we manage sources of pollution to Mediterranean wetlands?

38. How can we effectively and efficiently clean up polluted Mediterranean wetlands?

39. What are the minimum inputs of water needed to maintain major Mediterranean wetlands? How will their water balance be affected by climate change?

40. How effective are Ramsar sites in the Mediterranean? Are there any lessons to be learned from the most and least successful sites?

41. How should we manage protected areas involving Mediterranean wetlands, including the Ramsar network, in the face of climate change?

42. How effective are different conservation scenarios in protecting Mediterranean wetlands and their biodiversity? How, and why, might future approaches to conservation differ across the Mediterranean?

43. What are the services provided by Mediterranean wetlands under different management scenarios? What are the trade-offs when managing Mediterranean wetlands for different services?*

44. How can we mitigate disservices of Mediterranean wetlands but with minimal environmental damage?

45. How can we effectively engage citizens (farmers, fishermen, hunters, the public, etc.) in management and monitoring of Mediterranean wetlands?

46. Are existing large-scale conservation policies appropriate for the conservation of Mediterranean wetlands? If not, how might they be adapted for Mediterranean wetlands?

47. How can principles from the EU's Water Framework Directive be used to benefit Mediterranean wetlands outside the EU?

48. What indicators can be used to monitor the condition and functioning of Mediterranean wetlands?

Cross-cutting questions

49. How will key stressors or drivers of change interact to affect Mediterranean wetlands and their biodiversity?*

50. What are possible scenarios for positive futures relating to Mediterranean wetlands? How do we achieve them?

\section{Physical environment and climate change}

Our list includes four issues related to physical environmental change that are well known, but should not be ignored due to their likely large impact on Mediterranean wetlands: increasing average and maximum temperatures [I10]; declining total precipitation and associated droughts/desertification [I11]; increasing frequency and intensity of storms [I12]; and sea level rise [113]. Although these issues are commonly considered under the umbrella of climate change, we thought it was useful to separate them since they each have distinct impacts on Mediterranean wetlands and will demand different management responses. These issues pose existential threats to Mediterranean wetlands by reducing, increasing or altering the quality/timing of water supply, and through their contributions to coastal erosion (Jeppesen et al. 2015; Reimann et al. 2018). Human responses to climate change, such as construction of dams and reservoirs to store water and generate hydropower, may also be in conflict with biodiversity conservation goals (Hermoso 2017). Important research questions under this theme focused on quantifying the effects of climatic changes on Mediterranean wetlands and their biodiversity [Q6-9].

Our horizon scan suggested that the likely increased frequency of dust storms [130] and increasing fire risk [I31] over the next 30 years are currently underappreciated in the context of Mediterranean wetlands. These issues are linked to the aforementioned climatic changes [110-12]. Although dust storms and fires may threaten many Mediterranean wetlands, they may help to mitigate impacts of other issues. For example, fires could help to control succession in abandoned or eutrophicated wetlands (Zacharias and Zamparas 2010). Understanding the effects of acidification on Mediterranean wetlands was identified as an important research question [Q10].

\section{Biotic environment, ecology, biodiversity}

Over the next 30 years, the number and distribution of alien species in Mediterranean wetlands is likely to increase [I14], associated with increasing connectivity within the Mediterranean and to the rest of the world through transport and trade links (e.g. Anon 2019; UFM 2020). To inform conservation plans, it is important to forecast which species are likely to be introduced, to establish and to have negative impacts in Mediterranean wetlands generally or in specific sites [Q11], and to understand what measures are effective for preventing these processes [Q12]. There is also likely to be an increase in the frequency and distribution of microalgal and cyanobacterial blooms [I15], linked to many of the other highlighted issues, such as poor waste water treatment and dust storms.

Populations of many native, wetland-dependent species have been declining over the past half-century (MWO 2018; Fraixedas et al. 2019). It seems likely that these trends will continue [I16] given the pressures highlighted in our horizon scan and their cumulative effect on habitat fragmentation [I17]. Loss of species 
will likely affect the functions, services and value of Mediterranean wetlands, but perhaps these impending losses can be used as a call to arms for wetland conservation. Equally, can arguments around the need to maintain connected wetland networks be used to encourage conservation of strategic sites? Several research questions call for a better understanding of the issues affecting biological populations and communities in Mediterranean wetlands [Q13-18] to help guide conservation prioritisation and management.

The four underappreciated issues under this theme relate to disease in wetlands: either novel wildlife pathogens and diseases [132] or pathogens and diseases that can infect humans [133-35]. These latter issues could pose a threat to Mediterranean wetlands by encouraging environmentally damaging management such as hydrological modification or spraying with insecticides. However, they could equally encourage improvements in water quality, for instance through a switch to alternative methods to kill insecticide-resistant mosquito larvae, or through improvements to wastewater treatment to minimise the risk of antimicrobial resistance developing (Bueno et al. 2018). Further research into the relationship between Mediterranean wetlands and antimicrobial resistance is particularly desirable [Q19] to support evidence-based management decisions.

\section{Ecosystem services and use of wetlands}

Wise use of wetlands is a core tenet of the Ramsar Convention. Our horizon scan identified loss of traditional livelihoods involving sustainable use of Mediterranean wetlands as a critical issue [I18]. Intensification could directly or indirectly harm wetlands (Mathevet et al. 2015), whilst abandonment could lead to regime shifts (e.g. from open marshes to shrubby swamps) or deliberate conversion to other uses with a greater economic value (Save Salina 2020). Our horizon scan also highlighted the underappreciated threat of sand and gravel extraction, in or near wetlands [I36]. Trends of increasing aggregate extraction, primarily for construction, are likely to continue (UNEP 2016) with severe consequences for the physical wetland habitat (Peduzzi 2014; Koehnken et al. 2020).

Questions under this theme mostly relate to (a) the relationship between service provision and intensity of use [Q20], condition [Q21] or naturalness [Q22]; and (b) how Mediterranean wetlands can contribute to climate change adaptation [Q23] or mitigation [Q24]. There is also one broad question about services and disservices in the context of Mediterranean wetland and human health [Q25].

\section{Socioeconomics}

Several issues highlight the relationship between Mediterranean wetlands and the overall socioeconomic and political status of a country or region. In this respect, it is worth acknowledging that the Mediterranean region is highly heterogeneous with a great variety of socioeconomic and political situations, many of which have radically changed over the past decade. Over the next 30 years, socioeconomic instability [I37] and poverty [I38], especially as a result of climate change [I21], could divert attention and resources away from Mediterranean wetland conservation to more immediate human needs (e.g. providing food, financing the military). Mediterranean wetlands may also be direct casualties of conflict (Pacific Institute 2020) and are often a focus of international tensions (e.g. Rivers Tigris, Euphrates and Nile; see also I44). However, investment in wetland protection, restoration and creation could be promoted as a solution to socioeconomic problems (Adams et al. 2004; Ramsar Convention on Wetlands 2018).

The human footprint from tourism [I19] and urban areas [I20] is large in the Mediterranean and is likely to increase, especially in coastal zones (UNEP/MAP 2017; MWO 2018) - although tourist movements have dropped during the COVID-19 outbreak and are likely to remain depressed in the near future (OECD 2020). One research question encourages more detailed examination of future land use conflicts involving Mediterranean wetlands [Q26]. Another research question specifically asks how we can balance human development and Mediterranean wetland conservation [Q27]. Both of these questions are likely to have highly context-dependent answers.

Future economic policies could affect Mediterranean wetlands. Commitments to develop the "blue economy" based on use of the Mediterranean Sea [I39] could place additional burdens on already stressed marine and coastal wetlands (Bennett et al. 2019; see also Q49), but equally wetland protection and restoration could be an integral part of a "sustainable" blue economy. Meanwhile, it is possible that there will be major shifts in attitudes to development in the Mediterranean, away from purely economic growth and towards environmental conservation and human wellbeing [I40]. Wetlands would be a crucial part of this future.

It is likely that Mediterranean wetland management, conservation and research will continue to suffer from limited funding [I41]. Engaging the private sector in wetland conservation [Q28] could bolster funding, as could information on the net economic value of Mediterranean wetlands [Q29] and the net payoff, in economic terms or otherwise, of conserving them [Q30]. 
Public attitudes and behaviour can fundamentally affect environmental management, and inclusive, socially acceptable conservation should take these into account (Bennett 2016). Accordingly, we also identified research questions regarding general societal perceptions of Mediterranean wetlands [Q31] and the design of effective communication strategies for increasing public understanding and changing public behaviour [Q32].

\section{Governance}

Our horizon scan highlighted perceived deficiencies in the governance of wetlands, at both national and supranational scales, that are likely to continue into the future. Environmental conservation in the Mediterranean is often limited by weak governance [I22], including bureaucratic and compartmentalised political structures, ineffective decision-making mechanisms, inconsistent law enforcement and disagreements between countries (Mansourian 2012; Podimata and Yannopoulos 2016; Zapata-Barrero 2020). Most Mediterranean countries also lack a specific National Wetland Policy [142] that would help guide effective, efficient and coordinated management (Ramsar Convention Secretariat 2010). Even where rules are effectively exercised and enforced, they may be weak and full of loopholes [I23] or even encourage wetland degradation [I24]. It would be valuable to explore governance further in the context of Mediterranean wetlands, especially to identify specific elements that have the greatest influence on wetland conservation [Q33].

Our horizon scan optimistically considers that improved communication strategies will help to bring Mediterranean wetlands onto the policy agenda [I43], and that this could have a big effect on these habitats. However, there are outstanding research needs in regarding the efficacy of the science-policy interface [Q34] and how scientists and advocates can effectively communicate the value of wetlands to policymakers [Q35].

\section{Management and monitoring}

Many Mediterranean wetlands or watersheds cross national or regional borders, presenting both challenges and opportunities for management [I44]. Conflicting interests and the tragedy of the commons could threaten the existence of, and services provided by, transboundary wetlands (Mutahi 2020). However, collaborative conservation of Mediterranean wetlands could present a means to increase conservation effectiveness (PAP/RAC 2019) and reduce costs (Allan et al. 2019). Artificialisation [I25] is often seen as a threat to
Mediterranean wetlands but could present opportunities for managment to benefit biodiversity and/or people.

Several emerging technologies, or technological developments, have the potential to improve management or monitoring of Mediterranean wetlands over the next 30 years: sampling eDNA and eRNA to characterise biological populations or communities [I45]; using artificial intelligence to process data [I46]; smart urban water management, involving a multitude of sensors across cities and near-real-time analysis and forecasts [I47]; improvements in drone technology and reductions in cost [I48]; and the use of social media to understand how people interact with Mediterranean wetlands [I49]. The horizon scan also considered that knowledge-sharing networks will continue to facilitate effective management of Mediterranean wetlands [150], even if their value is currently underappreciated.

Fourteen of the 50 research questions are classified within the current theme. Four questions demand research on how to deal with specific threats facing Mediterranean wetlands [Q36-39, see also Q12]. Four questions demanded research on broad conservation strategies or scenarios, with a focus on comparing possible future options [Q40-43]. There are also questions on: mitigation of Mediterranean wetland disservices, such as flooding and zoonotic disease, with minimal environmental side effects [Q44]; engaging citizens in monitoring and management of Mediterranean wetlands [Q45]; the relevance and transferability of large-scale conservation policies for Mediterranean wetland conservation [Q46-47]; and indicators for monitoring Mediterranean wetlands [Q48].

\section{Cross-cutting questions}

Although many of our issues and questions could fit into multiple themes, we retained two research questions that relate to, or integrate, most of the themes. One considers how key stressors might interact to affect Mediterranean wetlands and their biodiversity [Q49]. The other, more optimistic question suggests identification of positive future scenarios for Mediterranean wetlands, and planning the steps to achieve these [Q50].

\section{Discussion}

\section{Issues and questions for Mediterranean wetlands 2020-2050}

Through a virtual process of community solicitation and democratic prioritisation, we have identified $50 \mathrm{key}$ issues that might affect Mediterranean wetlands over the next 30 years, and 50 important research questions that could improve conservation of these important but threatened systems. 
Mediterranean wetlands exist in a vast array of human, physical and biological contexts. The effects of many issues identified by our horizon scan, and answers to many of our research questions, will vary widely across the region. For example, changes in precipitation [I11] are likely to vary geographically in magnitude and even direction (Paxian et al. 2015; Quintana-Seguí et al. 2016). Post-COVID-19 paradigm shifts regarding societal development [I40] will probably not occur in all countries, and where they do the speed will likely vary. Appropriate management structures will depend on the biological and human context (Ernoul and Wardell-Johnson 2013). Our lists give a broad overview for the entire Mediterranean region to initiate debate and discussion. For any particular local context, issues and questions will need to be refined or removed, and new locally relevant issues or questions may be added.

Many of the identified issues are highly related and linked by feedback loops. For example, abstraction from coastal aquifers [I4] could lead to salinisation of groundwater and groundwater-fed coastal wetlands [I7], perhaps increasing pressure to build dams to guarantee freshwater supplies [I5] for agriculture [I1], tourism [I19] and urban areas [I20]. However, dams could in turn starve downstream wetlands of their water supply, increasing salinity [I7], and of their sediment supply, exacerbating the impacts of coastal erosion and sea level rise [I13]. Although we have categorised issues into themes, we recognise that holistic and cross-thematic thinking is essential for effective management of Mediterranean wetlands (e.g. Q49 and Q50).

Many of the issues are also double-edged, presenting both threats and opportunities for Mediterranean wetlands. For example, socioeconomic instability [I21 and I37] and poverty [I38] could divert resources away from Mediterranean wetland conservation (Bakker et al. 2010; Corlett et al. 2020). Alternatively, these issues present an opportunity to promote Mediterranean wetlands as sustainable solutions to societal problems (Barrett et al. 2011; Ramsar Convention on Wetlands 2018; IUCN French Committee 2019; Sebesvari et al. 2019). Stakeholders should be aware of these alternatives when making decisions.

Throughout the horizon-scanning process, we refined the issues and questions towards a similar, intermediate granularity (Wintle et al. 2017; Ockendon et al. 2018). We excluded some of the broadest indirect drivers of change, such as overall human population growth in the Mediterranean, human migration into and within the Mediterranean, and changing consumption patterns. The COVID-19 pandemic is another broad issue which emerged during our horizon-scanning process and is likely to influence many of the identified issues, from tourism (OECD 2020) to attitudes towards development (Arthus-Bertrand et al. 2020; Harvey 2020) and conservation funding (Corlett et al. 2020). Specific issues relating to single wetlands or countries were either generalised before the assessment, or filtered out during the assessment because they attracted low impact scores. Similarly, our list of key issues does not include "wildcard" events: surprising events with a large impact but a low likelihood of occurrence (Amanatidou et al. 2012).

It is striking that a substantial proportion of questions (26\%) relate primarily to management or monitoring [Q36-48], with several questions classified under other themes also asking how we can implement changes to benefit Mediterranean wetlands (e.g. Q1 and Q3). This does somewhat reflect patterns amongst submitted questions, although not precisely due to edits, merges and additions during the assessment. Interestingly, several submitted "questions" were in fact actions such as wetland creation, restoration and protection, and "fighting against pollution and the irrational exploitation of wetlands". Thus, there is clearly an appetite for taking action to conserve Mediterranean wetlands, and we encourage a sensible balance between action and research. Where practical conservation action is required, it should be informed by the best available evidence (Sutherland et al. 2004), but an absence of evidence should not be an excuse for inaction where it is needed. Meanwhile, further research can enhance the evidence base.

Several of the issues and questions relate directly to politics and governance (e.g. I22-24, I37, Q33-35). Crucially, many if not all of the others will be influenced by political decisions and governance structures (e.g. agricultural expansion driven by the European Union Common Agricultural Policy). Thus, achieving integrated, coordinated and effective governance at various spatial scales is a fundamental challenge for the conservation of Mediterranean wetlands - as for other regional and global ecosystems (Mansourian 2012; Amano et al. 2018). We suggest five possible routes to do so:

1. Improve the implementation of existing governance frameworks such as the Ramsar Convention (Geijzendorffer et al. 2019) and the Barcelona Convention (Frantzi et al. 2009)

2. Make the science-policy arena more interactive, with scientists and politicians working closely together to mutual benefit (Toomey et al. 2017)

3. Tackle corruption, nepotism and political self-interest, which remain a problem, to a greater or lesser degree, in all Mediterranean countries (Smith et al. 2003; Transparency International 2020)

4. Empower civil society and foster participatory approaches to conservation and management (WWF 2011)

5. Reassess goals for national and regional societal development, drastically reducing the weight given to economic outcomes (Otero et al. 2020) 


\section{Methodological strengths and weaknesses}

Our horizon-scanning and question-setting methods followed the general principles of previous projects (Sutherland et al. 2011; Ockendon et al. 2018; Sutherland et al. 2020; Wintle et al. 2020; Esmail et al. 2020), using community solicitation and literature reviews to generate a large pool of ideas, then iterative rounds of expert assessment and refinement. One distinct, although not completely novel, aspect of our process was that it was carried out entirely remotely rather than with an in-person workshop. Ideas were solicited through an online survey, expert assessment and feedback were performed in individual offline spreadsheets, and discussion took place via e-mail and on a live online spreadsheet. Remote working allowed democratic incorporation of a diverse range of perspectives. Remote scoring could be easily anonymised, avoiding psychological biases that may occur in group scoring situations (Burgman 2016). It also removed financial, temporal and logistical barriers associated with in-person workshops. It allowed more time to thoroughly research each issue between rounds of scoring/voting, ensuring decisions were based on evidence rather than opinion as far as possible. However, we do caution that this virtual process was slower than an in-person workshop. For example, each round of scoring/ voting was left open for 2-4 weeks to fit around assessors' other commitments. The virtual process encouraged some turnover in assessors (Fig. 3), but this was used as an opportunity to broaden the expertise involved in the overall process. Finally, virtual discussions are inherently less fluid and dynamic than face-to-face discussions, perhaps stifling critical and innovative thought, and hindering analysis of complex systems and interactions between events (Burgman 2016).

It is likely that the composition of our survey participant group and assessment panel influenced the nature of the issues and questions in our final lists (Burgman 2016). In particular, and despite our efforts to target individuals from diverse as well as underrepresented groups, we acknowledge that the survey participant group was dominated by people based in France and/or with expertise in biology and nature conservation. It is possible that major issues in underrepresented locations or within underrepresented subject areas were overlooked. However, highly localised issues would not have scored highly in our region-wide assessment, unless they affected critical habitats - and we would expect awareness of such issues across the Mediterranean. Overrepresentation of a certain group amongst the survey participants also had no influence on the weight given to an issue or question in the assessment. Each unique issue or question was carried forward to the assessment regardless of the number of survey participants who suggested it. Still, future updates to this horizon scan should include representatives from a broader range of locations, organisations and fields of expertise, to ensure the widest possible range of issues is captured. Amongst assessors, we acknowledge some bias towards people based in the north and west Mediterranean and with expertise in biology or nature conservation. However, expertise amongst the four sub-regions of the Mediterranean was almost perfectly balanced (Appendix 1b). Approximately half of the assessors considered themselves knowledgeable about issues across the whole Mediterranean. Furthermore, a recent analysis over 10 years of conservation horizon scans found that the subject area of identified issues was not significantly related to assessors' field of expertise (Sutherland et al. 2019).

We acknowledge that Delphi-like processes for soliciting group assessments have their weaknesses (Sackman 1974; Mukherjee et al. 2015; Burgman 2016). However, Delphi-like processes are widely used in horizon-scanning and question-setting exercises (Wintle et al. 2017; Sutherland et al. 2020; Esmail et al. 2020) as a credible, objective, traceable and efficient way to combine the expertise and opinions of a diverse group (Mukherjee et al. 2015). Moreover, we adjusted our method to address some of the known weaknesses of Delphi-like processes. To reduce the need to make snap judgments, we gave assessors ample time in each assessment round. To encourage careful responses, we included all assessors as authors on the resulting paper. To minimise the appearance of false precision, we present unranked lists of issues and questions. We acknowledge uncertainties and the influence of expert judgment (sometimes explicitly in the accompanying text to each issue; Appendix 2) and encourage more systematic forecasting of future trends.

\section{Conclusion}

We hope that our results will influence research, policy and practice related to Mediterranean wetlands and their conservation, and provide inspiration for similar projects on related topics (e.g. conservation in other Mediterranean-type regions around the world). We encourage the diversion of research effort towards the challenges, opportunities and knowledge gaps identified herein. Indeed, these have already been used to restructure the 2021-2025 research programme at Tour du Valat (Research Institute for the Conservation of Mediterranean Wetlands, Arles, France). Answering many of the research questions will require interdisciplinary research teams and regional collaboration. Our results highlight the importance of policy and effective, coordinated governance, at multiple spatial scales, in the future of Mediterranean wetlands. The identified issues can, in combination with additional foresight techniques such as roadmapping and modelling, be used to guide policy decisions. It would be valuable to repeat our analysis at regular intervals, updating priority issues and questions to reflect changes in our understanding, and in the regional or global context. 
Supplementary Information The online version contains supplementary material available at https://doi.org/10.1007/s10113-020-01743-1.

Acknowledgements We sincerely thank the survey participants for their contributions. We thank Arnaud Béchet, Suzanne Catteau, Florence Daubigney, Roberta Fausti, Ilse Geijzendorffer, Delphine Nicolas, Christian Perennou and Marion Vittecoq for their help with the initial development of this project. We thank Lisa Ernoul for help with initial data processing and Anis Guelmami for assistance with map preparation. We thank three anonymous reviewers for their feedback.

Funding WJS is funded by Arcadia.

\section{References}

Adams WM, Aveling R, Brockington D, Dickson B, Elliott J et al (2004) Biodiversity conservation and the eradication of poverty. Science 306:1146-1149. https://doi.org/10.1126/science.1097920

Allan JR, Levin N, Jones KR, Abdullah S, Hongoh J, Hermoso V, Kark S (2019) Navigating the complexities of coordinated conservation along the river Nile. Sci Adv 5:eaau7668. https://doi.org/10.1126/ sciadv.aau 7668

Amanatidou E, Butter M, Carabias V, Konnola T, Leis M et al (2012) On concepts and methods in horizon scanning: lessons from initiating policy dialogues on emerging issues. Sci Public Policy 39:208-221. https://doi.org/10.1093/scipol/scs017

Amano T, Székely T, Sandel B, Nagy S, Mundkur T et al (2018) Successful conservation of global waterbird populations depends on effective governance. Nature 553:199-202. https://doi.org/10. 1038/nature25139

Anon (2019) Morocco opens Mediterranean largest container port. http:// northafricapost.com/32210-morocco-opens-mediterranean-largestcontainer-port.html. Accessed 18 Apr 2020

Arthus-Bertrand Y, Barrau A, Bourg D, de Rostolan M, Giraud G et al (2020) Après le confinement, il nous faudra entrer en résistance climatique. https://www.lemonde.fr/idees/article/2020/03/19/apresle-confinement-il-nous-faudra-entrer-en-resistance-climatique 6033624_3232.html. Accessed 25 Apr 2020

Bakker VJ, Baum JK, Brodie JF, Salomon AK, Dickson BG et al (2010) The changing landscape of conservation science funding in the United States: conservation science funding. Conserv Lett 3:435444. https://doi.org/10.1111/j.1755-263X.2010.00125.x

Balbo AL, Martinez-Fernández J, Esteve-Selma M-A (2017) Mediterranean wetlands: archaeology, ecology, and sustainability: Mediterranean wetlands. WIREs Water 4:e1238. https://doi.org/10. $1002 /$ wat 2.1238

Balian EV, Segers H, Lévèque C, Martens K (2008) The Freshwater Animal Diversity Assessment: an overview of the results. Hydrobiologia 595:627-637. https://doi.org/10.1007/s10750-0079246-3

Balkız Ö, Béchet A, Rouan L, Choquet R, Germain C et al (2010) Experience-dependent natal philopatry of breeding greater flamingos: natal philopatry in adult flamingos. J Anim Ecol 79:10451056. https://doi.org/10.1111/j.1365-2656.2010.01721.x

Barrett CB, Travis AJ, Dasgupta P (2011) On biodiversity conservation and poverty traps. Proc Natl Acad Sci USA 108:13907-13912. https://doi.org/10.1073/pnas.1011521108

Bennett NJ (2016) Using perceptions as evidence to improve conservation and environmental management: Perceptions and Conservation. Conserv Biol 30:582-592. https://doi.org/10.1111/cobi.12681

Bennett NJ, Cisneros-Montemayor AM, Blythe J, Silver JJ, Singh G et al (2019) Towards a sustainable and equitable blue economy. Nat Sustain 2:991-993. https://doi.org/10.1038/s41893-019-0404-1
Brown LE, Mitchell G, Holden J, Folkard A, Wright N et al (2010) Priority water research questions as determined by UK practitioners and policy makers. Sci Total Environ 409:256-266. https://doi.org/ 10.1016/j.scitotenv.2010.09.040

Bueno I, Williams-Nguyen J, Hwang H, Sargeant JM, Nault AJ et al (2018) Systematic review: impact of point sources on antibioticresistant bacteria in the natural environment. Zoonoses Public Health 65:e162-e184. https://doi.org/10.1111/zph.12426

Burgman MA (2016) Testing judgements: how to get the best out of experts. Cambridge University Press, Cambridge

Cook CN, Inayatullah S, Burgman MA, Sutherland WJ, Wintle BA (2014) Strategic foresight: how planning for the unpredictable can improve environmental decision-making. Trends Ecol Evol 29:531541. https://doi.org/10.1016/j.tree.2014.07.005

Corlett RT, Primack RB, Devictor V, Maas B, Goswami VR et al (2020) Impacts of the coronavirus pandemic on biodiversity conservation. Biol Conserv 246:108571. https://doi.org/10.1016/j.biocon.2020. 108571

Cranfield University (2018) Horizon scanning toolkit, version 1.0. LIFE SMART Waste Project: Smarter Regulation of Waste in Europe (LIFE13 ENV-UK-000549).

Davidson NC, van Dam AA, Finlayson CM, McInnes RJ (2019) Worth of wetlands: revised global monetary values of coastal and inland wetland ecosystem services. Mar Freshw Res 70:1189-1194. https://doi.org/10.1071/MF18391

Dinerstein E, Olson D, Joshi A, Vynne C, Burgess ND et al (2017) An ecoregion-based approach to protecting half the terrestrial realm. BioScience 67:534-545. https://doi.org/10.1093/biosci/bix014

EEA (2019) Urban Waste Water Treatment Directive. https://www.eea. europa.eu/themes/water/european-waters/water-use-andenvironmental-pressures/uwwtd. Accessed 17 May 2020

Ernoul L, Wardell-Johnson A (2016) Representing the greater flamingo in southern France: a semantic analysis of newspaper articles showing change over time. Ocean Coast Manag 133:105-113. https://doi. org/10.1016/j.ocecoaman.2016.09.015

Ernoul L, Wardell-Johnson A (2013) Governance in integrated coastal zone management: a social networks analysis of cross-scale collaboration. Environ Conserv 40:231-240. https://doi.org/10.1017/ S0376892913000106

Esmail N, Wintle BC, t Sas-Rolfes M, Athanas A, Beale CM et al (2020) Emerging illegal wildlife trade issues: a global horizon scan. Conserv Lett. https://doi.org/10.1111/conl.12715

Ferrari K, Bellotti P, Dall'Aglio PL, Davoli L, Marta M, Torri P (2013) Wetlands in the river delta plains: evolution, values and functions during the Roman times. The coastal landscape close to the Garigliano river mouth. Geocarrefour 88:273-283

Fraixedas S, Galewski T, Ribeiro-Lopes S, Loh J, Blondel J et al (2019) Estimating biodiversity changes in the Camargue wetlands: an expert knowledge approach. PLoS ONE 14:e0224235. https://doi.org/ 10.1371/journal.pone.0224235

Frantzi S, Carter NT, Lovett JC (2009) Exploring discourses on international environmental regime effectiveness with Q methodology: a case study of the Mediterranean Action Plan. J Environ Manag 90: 177-186. https://doi.org/10.1016/j.jenvman.2007.08.013

GEBCO (2020) General Bathymetric Chart of the Oceans: gridded bathymetric data, 2020 grid. https://www.gebco.net/data_and_products/ gridded_bathymetry_data/. Accessed 28 Nov 2020.

Geijzendorffer IR, Beltrame C, Chazee L, Gaget E, Galewski T et al (2019) A more effective Ramsar Convention for the conservation of Mediterranean wetlands. Front Ecol Evol 7. https://doi.org/10. $3389 /$ fevo.2019.00021

Harvey F (2020) Covid-19 economic rescue plans must be green, say environmentalists. https://www.theguardian.com/environment/ 2020/mar/24/covid-19-economic-rescue-plans-must-be-green-sayenvironmentalists. Accessed 25 Apr 2020 
Hefny M, Amer SE-D (2005) Egypt and the Nile Basin. Aquat Sci 67:4250. https://doi.org/10.1007/s00027-004-0765-y

Hermoso V (2017) Freshwater ecosystems could become the biggest losers of the Paris Agreement. Glob Change Biol 23:3433-3436. https://doi.org/10.1111/gcb.13655

IUCN (2020) The IUCN Red List of Threatened Species. Version 20201. https://www.iucnredlist.org

French Committee IUCN (2019) Nature-based solutions for climate change adaptation \& disaster risk reduction. International Union for Conservation of Nature, Paris

Jeppesen E, Brucet S, Naselli-Flores L, Papastergiadou E, Stefanidis K et al (2015) Ecological impacts of global warming and water abstraction on lakes and reservoirs due to changes in water level and related changes in salinity. Hydrobiologia 750:201-227. https://doi.org/10. 1007/s10750-014-2169-x

Kark S, Sutherland WJ, Shanas U, Klass K, Achisar H et al (2016) Priority questions and horizon scanning for conservation: a comparative study. PLOS ONE 11:e0145978. https://doi.org/10.1371/ journal.pone. 0145978

Koehnken L, Rintoul MS, Goichot M, Tickner D, Loftus A et al (2020) Impacts of riverine sand mining on freshwater ecosystems: a review of the scientific evidence and guidance for future research. River Res Applic 36:362-370. https://doi.org/10.1002/rra.3586

Lehner B, Grill G (2013) Global river hydrography and network routing: baseline data and new approaches to study the world's large river systems. Hydrol Process 27:2171-2186

Mansourian S (2012) Natural resource governance in North Africa: challenges and opportunities. IUCN Social Policy and IUCN Mediterranean Programme

Mathevet R, Peluso NL, Couespel A, Robbins P (2015) Using historical political ecology to understand the present: water, reeds, and biodiversity in the Camargue Biosphere Reserve, southern France. Ecol Soc 20:art17. https://doi.org/10.5751/ES-07787-200417

Moreira F, Allsopp N, Esler KJ, Wardell-Johnson G, Ancillotto L et al (2019) Priority questions for biodiversity conservation in the Mediterranean biome: heterogeneous perspectives across continents and stakeholders. Conserv Sci Pract 1:e118. https://doi.org/10.1111/ $\operatorname{csp} 2.118$

Mukherjee N, Hugé J, Sutherland WJ, McNeill J, Van Opstal M et al (2015) The Delphi technique in ecology and biological conservation: applications and guidelines. Methods Ecol Evol 6:1097-1109. https://doi.org/10.1111/2041-210X.12387

Mutahi B (2020) Egypt-Ethiopia row: the trouble over a giant Nile dam. https://www.bbc.com/news/world-africa-50328647. Accessed 25 Apr 2020

MWO (2018) Mediterranean Wetlands Outlook 2: solutions for sustainable Mediterranean wetlands. Mediterranean Wetlands Observatory, Arles

Ockendon N, Thomas DHL, Cortina J, Adams WM, Aykroyd T et al (2018) One hundred priority questions for landscape restoration in Europe. Biol Conserv 221:198-208. https://doi.org/10.1016/j. biocon.2018.03.002

OECD (2020) Rebuilding tourism for the future: COVID-19 policy responses and recovery. http://www.oecd.org/coronavirus/policyresponses/rebuilding-tourism-for-the-future-covid-19-policyresponses-and-recovery-bced9859/. Accessed 25 Nov 2020

Otero I, Farrell KN, Pueyo S, Kallis G, Kehoe L et al (2020) Biodiversity policy beyond economic growth. Conserv Lett 13:e12713. https:// doi.org/10.1111/conl.12713

Pacific Institute (2020) Water conflict chronology. http://www. worldwater.org/conflict/map/. Accessed 25 Apr 2020

Papayannis T (2008) Action for culture in Mediterranean wetlands. MedINA, Athens

PAP/RAC (2019) The governance of coastal wetlands in the Mediterranean: a handbook. Priority Action Programme/Regional Activity Centre, Split
Parrinello G, Bécot R (2019) Regional planning and the environmental impact of coastal tourism: the Mission Racine for the redevelopment of Languedoc-Roussillon's littoral. Humanities 8:13. https://doi.org/ 10.3390/h8010013

Paxian A, Hertig E, Seubert S, Vogt G, Jacobeit J et al (2015) Present-day and future Mediterranean precipitation extremes assessed by different statistical approaches. Clim Dynam 44:845-860. https://doi.org/ $10.1007 / \mathrm{s} 00382-014-2428-6$

Payne R (2018) Peatlands of the Mediterranean region. In: Finlayson CM, Milton GR, Prentice RC, Davidson NC (eds) The wetland book: II: distribution, description, and conservation. Springer Netherlands, Dordrecht, pp 1155-1165

Peduzzi P (2014) Sand, rarer than one thinks. UNEP Global Environment Alert Service. https://wedocs.unep.org/handle/20.500.11822/8665. Accessed 28 Apr 2020

Perennou C, Beltrame C, Guelmami A, Tomàs Vives $\mathrm{P}$, Caessteker P (2012) Existing areas and past changes of wetland extent in the Mediterranean region: an overview. Ecol Mediterr 38:53-66. https://doi.org/10.3406/ecmed.2012.1316

Pérez-Jvostov F, Sutherland WJ, Barrett RDH, Brown CA, Cardille JA et al (2020) Horizon scan of conservation issues for inland waters in Canada. Can J Fish Aquat Sci 77:869-881. https://doi.org/10.1139/ cjfas-2019-0105

Plan Bleu (2010) Sea water desalination: to what extent is it a freshwater solution in the Mediterranean? Blue Plan Notes No. 16

Podimata MV, Yannopoulos PC (2016) A conceptual approach to model sand-gravel extraction from rivers based on a game theory perspective. J Environ Plan Manag 59:120-141. https://doi.org/10.1080/ 09640568.2014.991381

Quintana-Seguí P, Martin E, Sánchez E, Zribi M, Vennetier M et al (2016) Drought: observed trends, future projections. In: Moatti J$\mathrm{P}$, Thiébault $\mathrm{S}$ (eds) The Mediterranean region under climate change. IRD Éditions, Marseille, pp 123-131

Ramsar Convention on Wetlands (2018) Wetlands and the SDGs: scaling up wetland conservation, wise use and restoration to achieve the Sustainable Development Goals. Ramsar Convention Secretariat, Gland

Ramsar Convention Secretariat (2016) An introduction to the Convention on Wetlands. Ramsar Convention Secretariat, Gland

Ramsar Convention Secretariat (2010) National wetland policies: developing and implementing national wetland policies. Ramsar Handbooks for the Wise Use of Wetlands, 4th edition, Vol. 2. Ramsar Convention Secretariat, Gland

Reimann L, Vafeidis AT, Brown S, Hinkel J, Tol RSJ (2018) Mediterranean UNESCO World Heritage at risk from coastal flooding and erosion due to sea-level rise. Nat Commun 9:4161. https://doi.org/10.1038/s41467-018-06645-9

Sackman H (1974) Delphi assessment: expert opinion, forecasting, and group process. RAND Corporation

Save Salina (2020) The greed for money - the story of Ulcinj Salina. https://savesalina.net/the-story/. Accessed 20 Apr 2020

Sebesvari Z, Woelki J, Walz Y, Sudmeier-Rieux K, Sandholz S et al (2019) Opportunities for considering green infrastructure and ecosystems in the Sendai Framework Monitor. Prog Distaster Sci 2: 100021. https://doi.org/10.1016/j.pdisas.2019.100021

Smith RJ, Muir RDJ, Walpole MJ, Balmford A, Leader-Williams N (2003) Governance and the loss of biodiversity. Nature 426:6770. https://doi.org/10.1038/nature02025

Sutherland WJ, Adams WM, Aronson RB, Aveling R, Blackburn TM et al (2009) One hundred questions of importance to the conservation of global biological diversity. Conserv Biol 23:557-567. https://doi. org/10.1111/j.1523-1739.2009.01212.x

Sutherland WJ, Dias MP, Dicks LV, Doran H, Entwistle AC et al(2020) A horizon scan of emerging global biological conservation issues for 2020. Trends Ecol Evol 35:81-90. https://doi.org/10.1016/j.tree. 2019.10 .010 
Sutherland WJ, Fleishman E, Clout M, Gibbons DW, Lickorish F et al (2019) Ten years on: a review of the first global conservation horizon scan. Trends Ecol Evol 34:139-153. https://doi.org/10.1016/j. tree.2018.12.003

Sutherland WJ, Fleishman E, Mascia MB, Pretty J, Rudd MA (2011) Methods for collaboratively identifying research priorities and emerging issues in science and policy: identifying research priorities and emerging issues in science and policy. Methods Ecol Evol 2: 238-247. https://doi.org/10.1111/j.2041-210X.2010.00083.x

Sutherland WJ, Pullin AS, Dolman PM, Knight TM (2004) The need for evidence-based conservation. Trends Ecol Evol 19:305-308. https:// doi.org/10.1016/j.tree.2004.03.018

Sutherland WJ, Woodroof HJ (2009) The need for environmental horizon scanning. Trends Ecol Evol 24:523-527. https://doi.org/10.1016/j. tree.2009.04.008

Toomey AH, Knight AT, Barlow J (2017) Navigating the space between research and implementation in conservation: research-implementation spaces. Conserv Lett 10:619-625. https://doi.org/10.1111/conl. 12315

Transparency International (2020) Corruption Perceptions Index 2019. Transparency International, Berlin

UFM (2020) Motorway of the Sea (MoS) Turkey-Italy-Tunisia Project. https://ufmsecretariat.org/project/motorway-of-the-sea-mos-turkeyitaly-tunisia-project/. Accessed 18 Apr 2020

UNEP (2017) Frontiers 2017: emerging issues of environmental concern. United Nations Environment Programme, Nairobi

UNEP (2016) Global material flows and resource productivity: assessment report for the UNEP International Resource Panel. United Nations Environment Programme, Paris

UNEP/MAP (2012) State of the Mediterranean marine and coastal environment. United Nations Environment Programme \& Mediterranean Action Plan Barcelona Convention, Athens
UNEP/MAP (2017) 2017 Mediterranean Quality Status Report. United Nations Environment Programme \& Mediterranean Action Plan Barcelona Convention, Athens

van Rij V (2010) Joint horizon scanning: identifying common strategic choices and questions for knowledge. Sci Public Policy 37:7-18. https://doi.org/10.3152/030234210X484801

Walsh K, Attema P, de Haas T (2014) The Pontine Marshes (Central Italy): a case study in wetland historical ecology. Babesch 89:2746. https://doi.org/10.2143/BAB.89.0.3034668

Wintle BC, Boehm CR, Rhodes C, Molloy JC, Millett P et al (2017) A transatlantic perspective on 20 emerging issues in biological engineering. eLife 6:e30247. https://doi.org/10.7554/eLife.30247

Wintle BC, Kennicutt MC II, Sutherland WJ (2020) Scanning horizons in research, policy and practice. In: Sutherland WJ, Brotherton PNM, Davies ZG, Ockendon N, Pettorelli N, Vickery JA (eds) Conservation research, policy and practice, 1 st edn. Cambridge University Press, Cambridge, pp 29-47

WWF (2011) Voice of civil society seen as cornerstone of sustainable future for the Mediterranean. https://wwf.panda.org/es/?200830/1erCongreso-Internacional-Forestal-y-Viverista. Accessed $21 \mathrm{Apr}$ 2020

Zacharias I, Zamparas M (2010) Mediterranean temporary ponds. A disappearing ecosystem. Biodivers Conserv 19:3827-3834. https:// doi.org/10.1007/s10531-010-9933-7

Zapata-Barrero R (2020) Editorial: "Mediterranean thinking" for mapping a Mediterranean migration research agenda. Comp Migr Stud 8:6. https://doi.org/10.1186/s40878-019-0170-2

Publisher's note Springer Nature remains neutral with regard to jurisdictional claims in published maps and institutional affiliations.

\section{Affiliations}

Nigel G. Taylor ${ }^{1}$ (D) Patrick Grillas ${ }^{1} \cdot$ Hazem Al Hreisha ${ }^{2} \cdot$ Özge Balkız $^{3}$. Maud Borie ${ }^{1,4}$. Olivier Boutron ${ }^{1}$.

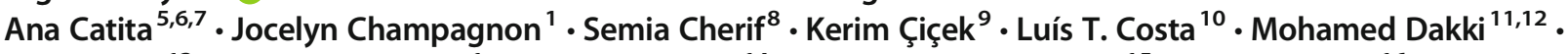
Mauro Fois ${ }^{13}$. Thomas Galewski ${ }^{1}$. Alessandro Galli ${ }^{14}$. Nicholas M. Georgiadis ${ }^{15}$. Andy J. Green ${ }^{16}$. Virgilio Hermoso ${ }^{17,18} \cdot$ Rezart Kapedani ${ }^{19} \cdot$ Manfred A. Lange ${ }^{20,21} \cdot$ Zoran Mateljak $^{22} \cdot$ Maher Osta $^{23}$. Eva Papastergiadou ${ }^{24}$ - Clairie Papazoglou ${ }^{25}$. Sergi Sabater ${ }^{26,27}$ • Boudjéma Samraoui $^{28,29}$ • Farrah Samraoui ${ }^{29,30}$. Abdelkrim Si Bachir ${ }^{31} \cdot$ Eva Tankovic $^{32}$ - Mathieu Thévenet ${ }^{32} \cdot$ Antonio Troya $^{33} \cdot$ William J. Sutherland $^{34}$

1 Tour du Valat, Research Institute for the Conservation of Mediterranean Wetlands, 13200 Arles, France

2 Azraq Wetland Reserve, P.O. Box 1215, Jubeiha 11941, Jordan

3 Doğa Koruma Merkezi (Nature Conservation Centre), Çiğdem Mah. 1594. Sok. No:3 06530, Çankaya, Ankara, Turkey

4 Department of Geography, King's College London, London WC2R 2LS, UK

5 Development and Innovation Network (RCDI), Centro Empresarial de Grândola, Fracção E - Incubadora de Empresas- Estrada da Aldeia do Futuro, 7570-272 Grândola, Portugal

6 Associação Portuguesa de Geógrafos, Instituto de Ciências Sociais, Av. Professor Aníbal Bettencourt, n. 9, 1600-189 Lisboa, Portugal
7 Associação Portuguesa para o Desenvolvimento Regional, Universidade dos Açores, Rua Capitão João D’Ávila, 9700042 Angra do Heroísmo, Portugal

8 Laboratoire de Recherche des Matériaux et de l'Environnement pour le Développement Durable (LR18ES10), ISSBAT, Université de Tunis El Manar, 9 Avenue Zouheir Essefi, 1006 Tunis, Tunisia

9 Section of Zoology, Department of Biology, Faculty of Science, Ege University, Izmir, Turkey

10 MAVA Foundation, Rue Mauverney 28, 1196 Gland, Switzerland

11 Département de Zoologie et Écologie Animale, Institut Scientifique, Université Mohammed V de Rabat, Rabat, Morocco

12 Centre d'Etude des Migrations d'Oiseaux (CEMO), Institut Scientifique, Université Mohammed V de Rabat, Rabat, Morocco 
13 Centro Conservazione Biodiversità, Dipartimento di Scienze della Vita e dell'Ambiente, Università degli Studi di Cagliari, Viale S. Ignazio da Laconi, 13, 09123 Cagliari, Italy

14 Global Footprint Network, Avenue Louis-Casaï, 18, 1209 Geneva, Switzerland

15 Mediterranean Institute for Nature and Anthropos (MedINA), 10671 Athens, Greece

16 Department of Wetland Ecology, Estación Biológica de Doñana, EBD-CSIC, Américo Vespucio 26, 41092 Sevilla, Spain

17 Centre de Ciència i Tecnologia Forestal de Catalunya (CTFC), Solsona, Spain

18 Australian Rivers Institute, Griffith University, Nathan, Queensland, Australia

19 Regional Environmental Center Albania, Rr. Ismail Qemali, No. 27, Kati/Floor 3, 1000 Tirana, Albania

20 Energy, Environment and Water Research Center, The Cyprus Institute, Nicosia, Cyprus

21 Future Earth MENA Regional Center at the Cyprus Institute, Nicosia, Cyprus

22 WWF Adria, Zelinska 2, 10000 Zagreb, Croatia

23 Society for the Protection of Nature in Lebanon, Awad Bldg, 6th Floor, Abdel Aziz Street, P.O. Box 11-5665, Beirut, Lebanon
24 Department of Biology, University of Patras, University Campus Rio, Patras 26500, Greece

25 P.O. Box 20495, Nicosia, Cyprus

26 Catalan Institute for Water Research (ICRA), Emili Grahit 101, 17003 Girona, Spain

27 Institute of Aquatic Ecology, University of Girona, Girona 17003, Spain

28 Department of Biology, University Badji Mokhtar Annaba, Annaba, Algeria

29 Laboratoire de Conservation des Zones Humides, Université 8 Mai 1945 Guelma, Guelma, Algeria

30 Department of Ecology, University 8 Mai 1945 Guelma, Guelma, Algeria

31 Department of Ecology and Environment, Faculty of Life and Nature Sciences, University of Batna 2, Batna, Algeria

32 Mediterranean Small Islands Initiative (PIM), Lycée des Calanques, 89 Traverse Parangon, 13008 Marseille, France

33 IUCN Centre for Mediterranean Cooperation, C/ Marie Curie 22, Edif. Habitec, Parque Tecnológico de Andalucía, 29590 Campanillas, Málaga, Spain

34 Department of Zoology, University of Cambridge, The David Attenborough Building, Pembroke Street, Cambridge CB2 3QZ, UK 